\title{
トピックス 吸収不良症候群と蛋白漏出性胃腸症
}

\section{II. 腸管における消化，吸収のメカニズム \\ 2. 水・電解質の吸収, 分泌機構とその異常}

\author{
花井 洋行 金子 榮藏
}

\begin{abstract}
要旨
腸管内腔には消化液, 食物飲水として $10 l /$ 日近い大量の電解質液が流入するが蕒便水はわず か $100 \mathrm{ml} /$ 日である. 近位小腸には食事の浸透圧の高・低にかかわらず大量の電解質プールを速 やかに体液と等張にする構造と機能が備わっている. 回腸, 結腸では活発にイオン（水）の吸 収・分泌が能動, 受動輸送を受けながら行われ最終的には $\mathrm{Na}^{+}, \mathrm{Cl}^{-}$, 水は殆んど再吸収される。 この過程は内分泌性, 傍内分泌性, 神経性に調節されており，このイオンの輸送異常が主要因 として生ずる下痢を分泌性下痢という。
\end{abstract}

〔日内会誌 $85 ： 1034 \sim 1041 ， 1996 〕$

Key words：等張性吸収，能動輸送，分泌性下痢

\section{はじめに}

消化管では 1 日に約7〜8lの消化液が分泌され， 食物摄取・飲水により $2 l$ 前後の水分が腸管内に流 入する.しかし，最終的には 1 日 $100 \mathrm{ml}$ 前後の䔬便 水を排泄するにすぎず， $99 \%$ が再吸収を受ける。 これは腎臓における系球体濾過量 $(150 \sim 170 l)$ に 対する尿生成 (1.5l) 過程の再吸収率と偶然にも一 致している.

消化管での水分調節の破綻はそこに含まれる電 解質（溶液中で解離し荷電した粒子，つまりイオ ンになりうる化学物質) の变失を伴うため, 酸・ 塩基平衡などの体液平衡に大きな影響を及ぼす。 たとえば長期の嘔吐や慢性の下痢では脱水を生ず るのみでなく, 前者では塩酸の過剩喪失による代 謝性アルカローシスを, 後者の場合は十二指腸の アルカリ性分泌液を失うため代謝性アシドーシス を生ずる.これら水とイオンの腸管での吸収とそ の調節機構はどのように行われているのであろう か.

総体液は細胞内液と細胞外液に分けられ，後者

はないひろゆき，かねこえいぞう：浜松医科大学 第一内科
はさらに血漿と細胞間質液より成る。この血漿と 細胞内液は同種のイオンが存在しているが，それ ぞれのイオン濃度は両者で非常に異なる。細胞外 液はその化学的組成が海水のそれとよく似ており

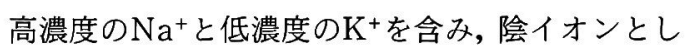
て高濃度のCl-を含んでいる.細胞内液はこれと正 反対である。また $\mathrm{Ca}^{2+}$ は細胞内外で 10,000 倍の濃 度勾配を有しており，これら全ての細胞内外のイ オン組成の差が細胞の生命にとって非常に重要な ことである.この濃度勾配を形成, 維持するため に細胞膜に種々の特殊な輸送機構が存在する. そ してこの機構が異常に作働したり，欠損している ことが様々な病態や疾患の病因となっている.

\section{1. イオン輸送機構の概要}

生体の電解質ホメオスターシスを維持するため に排泄，再吸収を調節的に行っている組織ではイ オンは経上皮的に輸送される。この経上皮輸送で は管腔から上皮細胞内へ入る経細胞輸送と細胞間 隙を通る細胞間輸送がある。経細胞輸送では $2 つ$ の膜を横切る必要があり, tight junctionを境に管 腔側の刷子緑膜と体液側の側底膜である (図 1a). この $2 つ の$ 生体膜は極性を有しており膜に組み込 
(a)

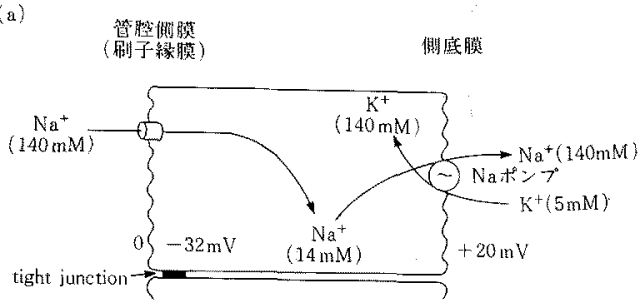

(b)

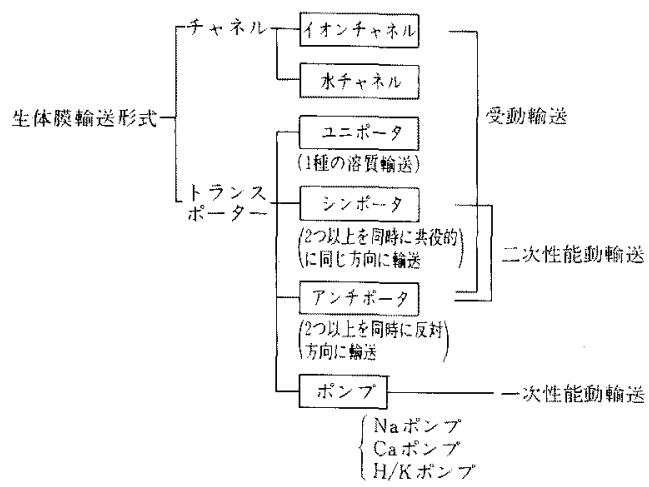

図 1. 経上皮細胞輸送の基本 (a)と生体膜輸送の様々 な形式（b)

まれている輸送蛋白が異なっている。このような 輸送担体蛋白の両者八の仕分けがどのように行わ れるかは興味のあるところであるが十分に解明さ れていない.

輸送形式には図1bに示すようにチャネルとト ランスポーター(輸送担体)がある。トランスポー ターにはいくつかの样式があり, ATPの加水分解 エネルギーを直接利用して電気化学ポテンシャル 勾配に逆らって溶質を輸送するトランスポーター をポンプと呼ぶ。イオンポンプにはNaポンプ (Na, K ATPase), Caポンプ(Ca, Mg ATPase), Hポンプ (H，K ATPase)がありこれを一次性 能動輸送という. 電気化学ポテンシャル勾配は膜 をはさんで，あるイオンの濃度差による化学的仕 事と電位勾配偟よる電気的仕事の和で決まる。二 次性能動輸送とはNaポンプで作られた $\mathrm{Na}^{+}$の電 気化学ポテンシャル勾配駆動力とするもので $\mathrm{Na}^{+}$が細胞内に向かうエネルギーを利用して， $\mathrm{Na}^{+}$と共役して他のイオンや溶質が能動輸送を受
ける様式をいう。電気化学ポテンシャル勾配に 沿った輸送が受動輸送である。また最近，トラン スポーターの構造を持ちながらもチャネルとして 働くような輸送体の存在が報告され注目されてい る.

\section{2. 水の輸送機構}

高張性の食事 $(630 \mathrm{mOsm} / \mathrm{kg})$ と低張性の食事 $(230 \mathrm{mOsm} / \mathrm{kg})$ を㨠取した場合，速やかに上部空 腸で体液とほほ同じ等張溶液 (280〜290mOsm/l) になるという実験結果がある。これはどのように して行われるのであろうか.

1）近位腸管 (十二指腸，上部空腸）での等張性 吸収

二種の食事後の近位腸管での水分移動量が著明

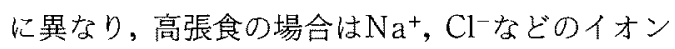
の動きに比べて速やかに水が体液側から管腔内容 を希釈するように動く，低張食の場合好管腔内容 を濃縮するように水がイオンの動きに比して速く 体液側に移動する。ここで重要なことは，イオン の輸送により生じた浸透圧の差により水は輸送さ れるのであり，イオンの輸送を阻害すれば水の輸 送も止まる点である。平衡に達した後注水やイオ ンの動きに両者で差は認めず，体液に類似したイ オン組成と濃度の腸管内容液が $5000 \mathrm{ml}$ も回腸に 流入する(表 1 )。このように近位腸管は管腔内の 水とイオンプールを速やかに体液と平衡させる構 造と機能を備えているのである。その構造とは， 陊り合わせの細胞間の結合がゆるめであり細胞間 隙路を容易にイオンや水が通過できることによ る。もともと細胞膜注脂質二重層で疎水性である ものの水の透過性は高い. 細胞内, 外液のイオン 組成が大きく異なるのに対し，漫透圧が同じであ るのはこの水の高い透過性による。しかしこの近 位腸管では紐胞間隙路を通過する水分量の方がは るかに多く, 電気化学ポテンシャル勾配に沿った 受動的な輸送のみが起こっている。まずイオンや 非電解質がこの間吵路に輸送され，同時に上皮細 胞内へチャネルやトランスポーターを介して吸収 るれた $\mathrm{Na}^{+}$は細胞質からNaポンプによって汲み 
表 1.人の消化液と腸内容液のイオン組成

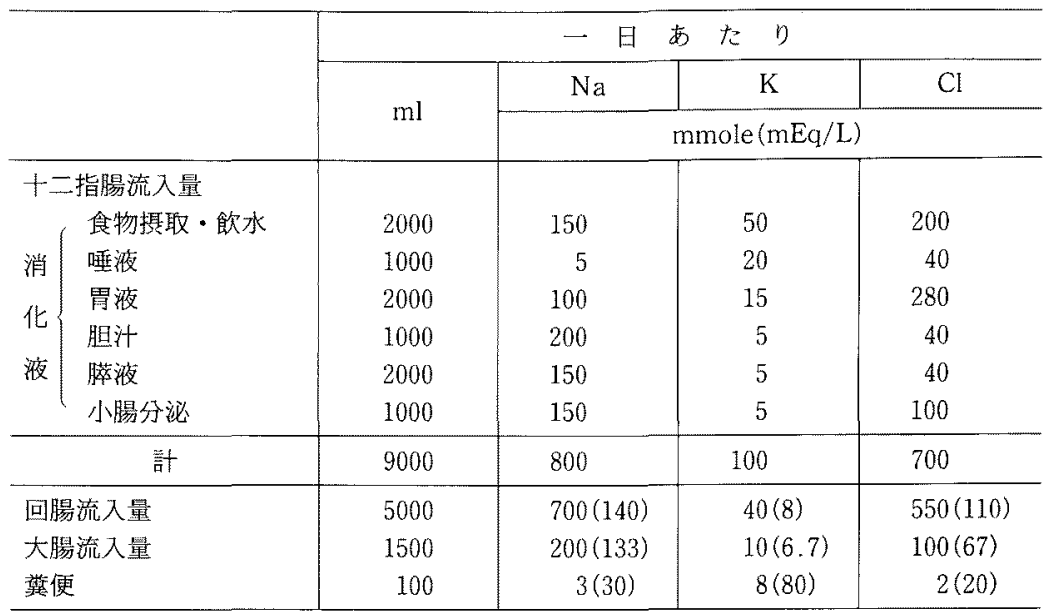

(1日に800ミリモルの $\mathrm{Na}^{+}$日700ミりモルのCl-が掑取，分泌され蕒便中では それぞれ3ミリモル，2ミリモルとなる．大腸には低浱度の $\mathrm{Na}^{+}, \mathrm{Cl}^{-}$溶液から 高濃度の $\mathrm{Na}^{+}, \mathrm{Cl}^{-}$の体液側に吸収する機能が必要である。

出され，細胞間隙路の浸透圧を上昇させる．同時 に，水はtight junctionを通ってこの細胞間陵路に 流入する。その結果，この部の浸透压は低下する が静水圧は上昇し, 水洼体液側へと輸送される. このようにして等張性溶液が吸収されたことにな る.

\section{2）遠位結腸における腸管内溶液濃縮能}

細胞間隙路の障壁となるtight junctionはイオ ン選択性があり, $\mathrm{Na}^{+}, \mathrm{K}^{+}$注 $\mathrm{Cl}$-の 2 倍の透過性が ある。必た腸管部位による透過性のheterogeneity (部位特異性)も存在する．細胞問隙の電気抵抗の 低い上皮はtight junctionの電気抵抗が低く，イオ ン透過性が高い.したがって水の輸送も起こりや すいことになる。大腸，特に遠位結腸では動物実 験によると近位腸管に比して，3〜10倍も電気抵 抗が高く細胞間吵路のイオンや水の透過が低い. 水透過性の高い上皮では少しの浸透圧差で水移動 が生ずるので等張性吸収となり，遠位結腸のよう に，透過性が低い部位では吸取される液の浸透圧 は吸収を受ける側の液の浸透圧より高くなり高浸 透压の粪便 (約 $400 \mathrm{mOsm} / \mathrm{kg}$ ) を生成する。また, この高浸透圧の驵便形成に峙後述するこの部位に のみ存在する起電性Naチャネルによるところが
大きい.

\section{3. イオンの輸送機構と調節}

水の吸収や分泌は必ずイオンや非電解質の輸送 に伴なって，その浸透圧効果によって二次的に起 こるものであり水の能動輸送は認められていな い. そ机故，イオンの吸収，分泌とその調節機序 が重要となる。

\section{1）イオン輸送のheterogeneityと生理的意義}

全腸管に亘って種々のイオン輸送機構が存在 L, heterogeneity (部位特異性)を持っている(図 2). 量的にも多く, 浸透圧効果に大きな影響を及 添し, 下痢発症の機序からも重要なのは $\mathrm{Na}^{+}, \mathrm{Cl}^{-}$ の輸送である。

(1) $\mathrm{Na}^{+}$と $\mathrm{Cl}^{-}$

(1) $\mathrm{Na}^{+} / \mathrm{Cl}^{-}$共役輸送

刷子縁膜で $\mathrm{Na}^{+}$と $\mathrm{Cl}^{-}$が $1 ： 1$ に電気的に中性 に輸送される。この本体は $\mathrm{Na}^{+} / \mathrm{H}^{+}$アンチポート (逆輸送) と $\mathrm{Cl}^{-} / \mathrm{HCO}_{3}$-アンチポートの両者が共 同して作働した結果, 正味で $\mathrm{Na}^{+}, \mathrm{Cl}^{-}$が細胞内に 1：1で吸収されるものである。細胞内に対して $\mathrm{Na}^{+}$は受動輸送であるがCl-は能動輸送を受ける。 
A. ナトリウム吸収

$\mathrm{Na}^{+} / \mathrm{H}^{+}$子交換 $\mathrm{Na}^{+}$樍、アミ酸 $\mathrm{Na}^{+} / \mathrm{Cl}^{-}$共役 $\mathrm{Na}^{+}$チャン゙ル

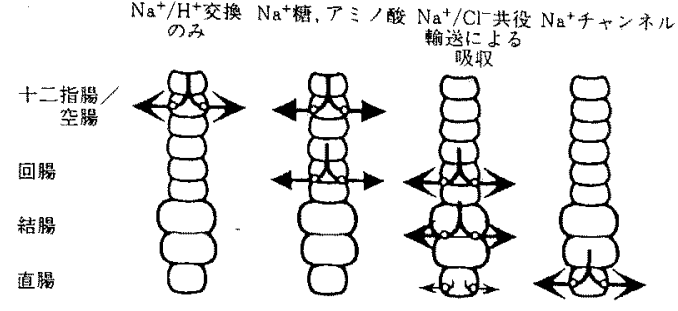

B. フロライド吸收

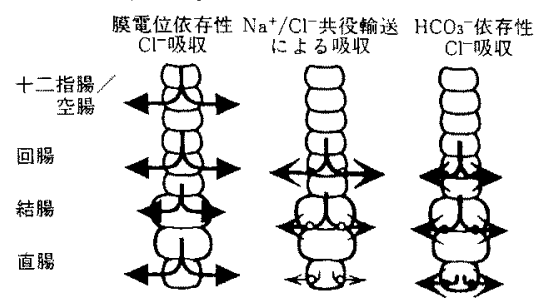

C. 力引ウ人翰送

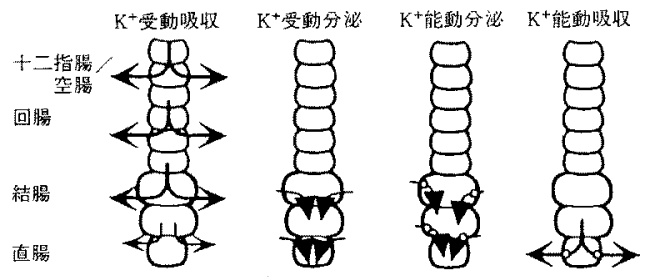

図 2、腸管における各イオン輸送のheterogeneity

このアンチポーターは回腸,近位結腸に存在し(図 $2)$, 腸管のイオン吸収の主役であり,種々のmediatorで促進や抑制をうけている。

\section{(2) $\mathrm{Na}^{+} / \mathrm{H}^{+}$逆輸送}

十二指腸, 空腸には $\mathrm{Na}^{+} / \mathrm{H}^{+}$アンチポートのみ が存在し, $\mathrm{Cl}^{-} / \mathrm{HCO}_{3}$-アンチポートは認めない. $\mathrm{H}^{+}$が管腔内に汲み出されるためやや酸性に傾き, 刷子縁膜直上ではpH 5.5にもなり ${ }^{1)}$ ，カルシウム や鉄の吸収に非常に役立っている。なぜなら塩と して食物掑取されたままでは吸収不能であり， $\mathrm{Ca}^{2+}, \mathrm{Fe}^{2+}, \mathrm{Fe}^{3+}$ のイオンになって初めて, 輸送 可能となるからである。つまりイオン化には酸が 必要であり，この $\mathrm{Na}^{+} / \mathrm{H}^{+}$アンチポートがその役 を担っている。特に無酸症や胃切除術後や強い酸 分泌抑制薬の長期服用患者にはかけがえのない酸 分泌機構と言えよう.

\section{(3) 起電性 $\mathrm{Na}^{+}$吸収}

これには糖やアミノ酸などの溶質を共輸送し栄
䝱吸収に役立っているものと，遠位結腸の刷子縁 膜に存在するNaチャネルがある。前者は別項にゆ ずるが後者は内向きの駆動力によって吸収をう け，細胞内に入った $\mathrm{Na}^{+}$は(1)，(2)の場合と同様に側 底膜のNaポンプによって汲み出される。遠位結腸 で低濃度となった $\mathrm{Na}^{+}, \mathrm{Cl}^{-}$溶液からさらに体液側 に吸収を可能にしている機構であり, 腎藏の集合 管に存在するものとよく似ておりアルドステロン により促進される。

(2) $\mathrm{K}$

全腸管に亘って受動的な $\mathrm{K}^{+}$吸収が観察され, 結 腸では受動輸送分泌も認められる.能動的な $\mathrm{K}^{+}$吸 収は $\mathrm{Na}^{+} に も$ 電位にも依存しない $\mathrm{H}^{+} / \mathrm{K}^{+}$アンチ

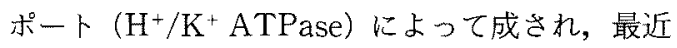
この遺伝子のクローニングが行われ, $\mathrm{Na}^{+} / \mathrm{K}^{+}$ ATPaseや型の $\mathrm{H}^{+} / \mathrm{K}^{+}$ATPase と60〜65\%の 相同性を示すことが明らかになっている.mRNA の発現から能動的な $\mathrm{K}^{+}$吸収の部位である遠位結 腸のみに認められている。また全身のNa+欠方状 態ではアルドステロンの上昇により遠位結腸での $\mathrm{K}^{+}$能動分泌を促進すると同時に前述の起電性 $\mathrm{Na}$ 吸収を促す。

\section{2）イオン・水輸送の調節機構}

上皮細胞内のセカンドメッセンジャー (cAMP, cGMP, $\mathrm{Ca}^{2+}$ ) は種々の内分泌性, 傍内分泌性, 神経性の刺激をうけイオン・水輸送を調節してい る.内分泌性としては, ガストリン, カルシトニ ン，グルカゴンなどが分泌促進に働く、バソプレ シンも $\mathrm{V}_{1} レ$ セプーを介して $\mathrm{Cl}^{-} や \mathrm{~K}^{+}$分泌と $\mathrm{Na}^{+}$の吸収抑制を示すことを確認している゙2.また インスリン,グルココルチコイドなどは吸収促進 作用を有する，傍分泌性の調節因子としてブラジ キニン，セロトニン，ヒスタミン，プロスタグラ ンジンなどが分泌促進作用を有する。これらは炎 症，アレルギー反応時に放出される物質であり生 体防御反応としてのイオン・水の分泌促進効果と も言光よう。神経性調節として神経伝達物質のア セチルコリン, セロトニン,サブスタンスPなどが $\mathrm{Na}$ 吸収抑制, $\mathrm{Cl}^{-}$分泌, 水分泌促進効果在持古, 力 テコラミンは吸収促進に㗢く。

この他に門脈血中の高 $\mathrm{Na}^{+}$濃度を感知し自律神 
経を介して空腸での $\mathrm{Na}^{+}$の吸収抑制が生ずる，肝 腸反射の存在も指摘されている ${ }^{3}$. 一方, 最近水輸 送の直接の調節機構として $\mathrm{ADH}$ 感受性水チャネ ルが腎・集合管の刷子緑膜に存在することが報告 された ${ }^{4)}$ このチャネル蛋白はアクアポリン (AQP 2)と命名され，現在までに哺乳類で 5 種類 (AQP 1-5）の存在が認められている．消化管にも大腸 の陰營上皮細胞の側底膜, 吸収上皮細胞の側底膜, 胃，食道上皮細胞の側底膜に存在することが確認 されている.しかし，残念なことにこれら消化管 に存在するAQPの生理機能は全く解明されてい ない.

\section{4.イオン・水輸送の異常}

健常者では回盲弁を通過する水分は $1500 \mathrm{ml}$ あるが下痢をしないためのそのcapacityは5000 $\mathrm{ml}$ と大きい(図 3 )。しかし大腸にイオン・水輸送 に異常があるとたとえ大腸への水分流入量が正常 であっても下痢を来たす。

\section{1）浸透圧性下痢}

管腔内に非吸収性の浸透王効果をもたらす溶質 が存在すると水の分泌過剩となる。これが浸透圧 性下痢である。この機序で下疮を生じうるものと して塩類下羭(硫酸塩，燐酸塩），マグネシウムを
含んだ制酸薬，ラクチュロース（腸管で消化され ない合成二糖類) 投与や二糖類分解酵素欠乏症(乳 糖不耐症, isomaltase-sucrase欠之症）などがあ る、毎日大量にチューインガムをかむことにより 慢性下痢を生じた例もある。これはガムに含まれ るソルビトールによるものである。

\section{2）浸出性下㾝}

腸粘膜障害のため粘膜の浮腫, 充血, 潰瘍形成 などにより腸粘膜の透過性が元進した場合であ る。多量の浸出液が分泌されると同時に吸取障害 も加わった病態となる。潰癔性大腸炎, Crohn病, 腸結核, 抗生物質関連性腸炎, 放射線性腸炎, 食 事アレルギーやウイルス性腸炎などがこれに相当 する。

\section{3）分泌性下痢}

腸上皮細胞におけるイオン輸送の異常にもとづ く下痢をいう。

\section{（1）起因物質とそれに関する疾患}

異常な mediatorが細胞内のcAMP，cGMP， $\mathrm{Ca}^{2+}$ な゙のセカンドメッセンジャーに変化を与 え $\mathrm{Na}^{+}, \mathrm{Cl}^{-}$の吸取を扸制したり起電性の $\mathrm{Cl}^{-}$分泌 を刺激して水分泌を生ずるものである。このmediatorkなり得るものは表 2 に示すように多彩であ る.WDHA症候群では血漿中のVIP (vasoactive intestinal polypeptide), GIP (gastric inhibitory

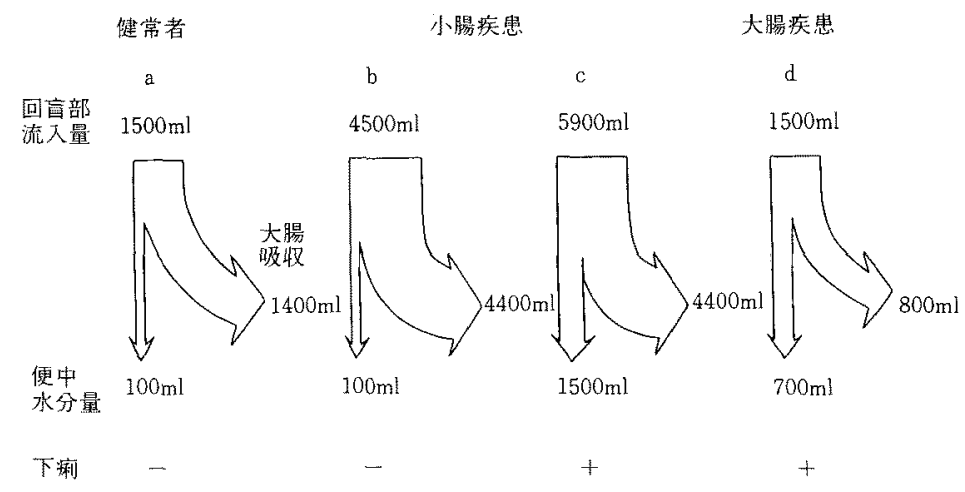

揵常者では大腸八の水分流入量注 1 日に $1500 \mathrm{ml}$ である゙そのcapacityは $5000 \mathrm{~m}$ 前後あるのでなと之小腸での水分吸取が不十分で毛代償しうる この量は基本的に管腔内の $\mathrm{Na}^{+}, \mathrm{Cl}^{-} の$ 吸收量に依存しているがアルドス テロンやグルココルナコイドなど内的因子の調節を受けている。

図 3，便中水分量の調節㵴睘としての大腸 
表 2. 分泌性下痢を来たす病因（起因物賀）上疾㭧

\begin{tabular}{|c|c|}
\hline 区 & 疾 \\
\hline 細菌性エンテロトキシン & コレラ, 病原性大腸菌による下痢 \\
\hline エンテロウイルス（ロタウイルス） & ウイルス性腸炎 \\
\hline $\begin{array}{l}\text { Dihydroxy胆汁酸 } \\
\qquad\left(\begin{array}{l}\text { chenodeoxycholic bile acids } \\
\text { deoxycholic bile acids }\end{array}\right)\end{array}$ & $\begin{array}{l}\text { 回腸病変 (Crohn病, 結核) } \\
\text { 回腸, 回旨部切除 } \\
\text { 迷走神経切断倠 } \\
\text { 胆のう摘出術 }\end{array}$ \\
\hline $\begin{array}{l}\text { 長鎖脂肪酸の分解産物 } \\
\text { (10水酸化ステアリン酸) }\end{array}$ & $\begin{array}{l}\text { 脂肪便を生ずる疾㭧 } \\
\text { (膵機能障害, 腸性脂肪便など) }\end{array}$ \\
\hline $\begin{aligned} \text { 緩下剤 } & : \text { 七シ油(リシノール酸) } \\
& : \text { センナ } \\
& : \text { フェノールフタレイン系薬物 }\end{aligned}$ & \\
\hline $\begin{array}{r}\text { 腫湯産生ホルモン } \\
\text { ガストリン }\end{array}$ & Zollinger-Ellison症候群 \\
\hline $\begin{array}{l}\text { VIP, PP } \\
\text { GIP } \\
\text { カルシトニン, } \\
\text { プロスタグランジンなど }\end{array}$ & $\begin{array}{l}\text { WDHA症㸻群 } \\
\text { 別名膵コレラ, VIP-oma症候群, Verner-Morrison症 } \\
\text { 候群とも呼ばれる. }\end{array}$ \\
\hline $\begin{array}{l}\text { カルシトニン } \\
\text { プロスタグランジン }\end{array}$ & 甲状腺髄様癌 \\
\hline セロトニン & カルチノイド腚候群 \\
\hline 一酸化空素 $(\mathrm{NO})$ & 炎症性腸疾患 (Crohn病・潰瘍性大腸炎) \\
\hline 先天性翰送担体蛋白欠抯 & $\begin{array}{l}-\mathrm{Cl}^{-} / \mathrm{HCO}_{3}{ }^{-} \text {交換輸送欠損(先天性クロール下疾症) } \\
\text { - } \mathrm{Na}^{+} / \mathrm{H}^{+} \text {交換輸送欠損 }\end{array}$ \\
\hline 原因不明 & $\begin{array}{l}\text { Nonulcerative Colitis } \\
\text { - microscopic大腸炎 } \\
\text { - collagenous大腸炎 }\end{array}$ \\
\hline
\end{tabular}

polypeptide), PP (pancreatic polypeptide), ロスタグランジン，カルシトニンなどが上昇して いるがどの物質が直接の mediatorかはっきりし ていない，浸出性下痢の項目に挙げた潰瘍性大腸 炎やCrohn病などの炎症性腸疾患でも分泌性下疮 の機序が関与していることが示されている。これ は一酸化窒素 $(\mathrm{NO})$ がmediatorとなっている。大 腸に流入したdihydroxy胆汁酸もcAMPを上昇さ せ分泌性下痢をおこす，大腸にびらん，潰瘍もな く生検所見で形質細胞と好中球の浸潤を認める場 合がある.これらはmicroscopic colitisやcollagenous colitisと呼ばれているが大腸でのイオ ン，水の吸収障害による分泌性下痢が認められて いる．自己免疫疾患を有する中年の女性に頻度が
高いとされるが必ずしも全身疾患との明らかな関 連は指摘されていない. 先天性の輸送担体が欠損 するために生ずる下痢も細胞内セカンドメッセン ジャーに変化はないがイオン輸送異常にもとづく

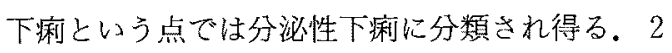
タイプの報告があり 1 つは回腸と大腸に存在す心゙ き $\mathrm{Cl}^{-} / \mathrm{HCO}_{3}$-アンチポーターが欠損したもので, 先天性クロール下痢症 (congenital chloridorrhea with alkalosis) と呼ばれ， $\mathrm{Na}^{+} / \mathrm{H}^{+}$アンチポー ターは正常に存在するので管腔内は酸性となり高 濃度の $\mathrm{Cl}^{-}$が便中に排泄される.当然のことながら 血獎の $\mathrm{Cl}^{-}$は低くアルカローシスとなり低 $\mathrm{K}$ 血症 を来たし，持続する下痢のため血漿 $\mathrm{Na}^{+} も$ 低值と なり二次性アルドステロン症となる。常染色体劣 


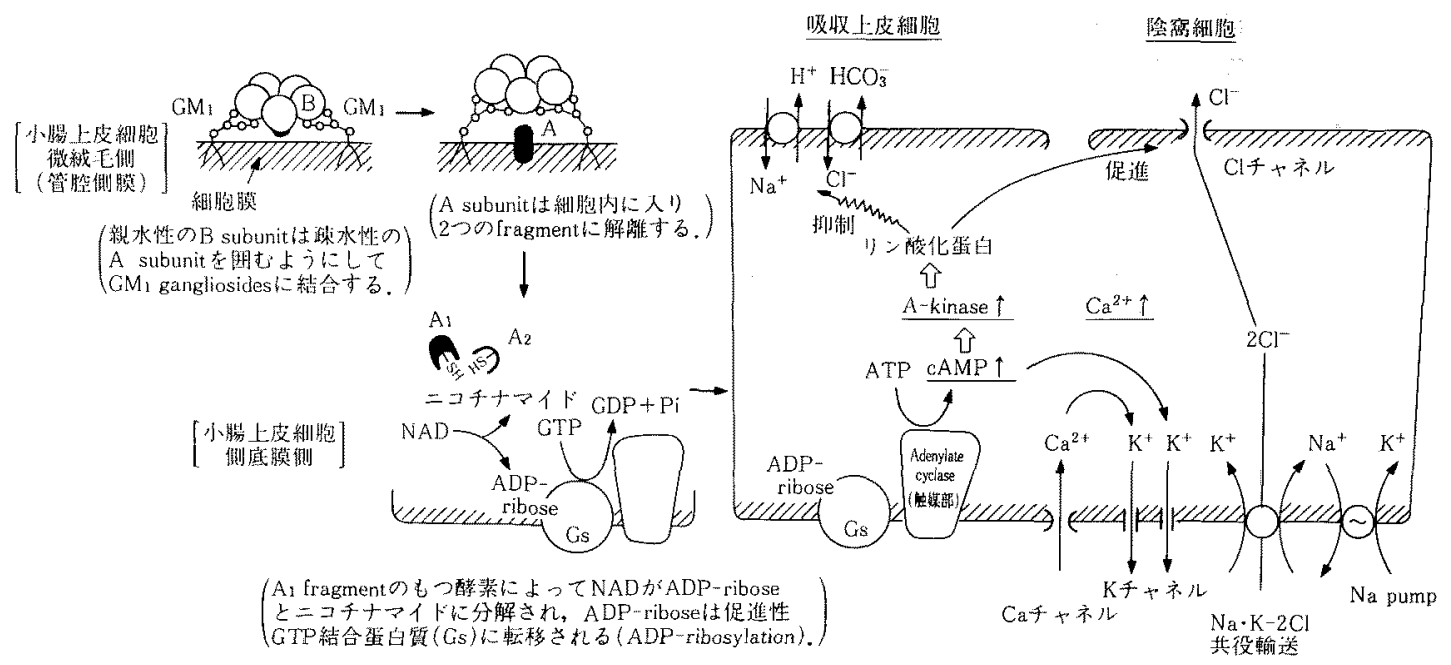

図 4、コレラトキシンによる下莉発症の機序（支献５より改変）

性遗伝である。また $\mathrm{Na}^{+} / \mathrm{H}^{+}$アンチポーターを欠 損して下㢉を生じ代謝性アシドーシスをきたす異 常も報告されている。これらは高浸透圧性下痢の 因子も関与することになる。

（2）分泌性下痢の機構

分泌性下痢の代表的なものとしてコレラトキシ ン (CT) よって生ずる下痢が膜輸送, 生化学, 分 子レベルで研究がすすんでいる(図 4)。CTが細 胞膜上のレセプターである $\mathrm{GM}_{1}$ ガングリオシド に結合し，いくつかの過程を経で5細胞内の CAMPを上昇させる.この結果刷子縁膜上の $\mathrm{Na}^{+} /$ $\mathrm{H}^{+}$アンチポーター, $\mathrm{Cl}^{-} / \mathrm{HCO}_{3}^{-}$アンチポーター が阻害されそその結果生ずる $\mathrm{Na}^{+}$とCl一の吸収抑制 と,陰窩部細胞での起電性 $\mathrm{Cl}^{-} の$ 分泌促進に伴う等 張性体液の分泌を促進する。この時側底膜の $\mathrm{K}^{+}$

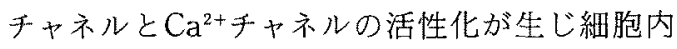
のCa ${ }^{2+}$ が昇する。これはまたK $\mathrm{K}^{+}$チャルルを開き $\mathrm{Na}^{+}$ポンプで生じたNa+の電気化学ポテンシャル 勾配を駆動力とし， $\mathrm{Na} \cdot \mathrm{K} \cdot 2 \mathrm{Cl}$ シンポートが作働 する.つまり $\mathrm{Na}^{+}$と $\mathrm{K}^{+}$のrecycleと連動して刷子 緑膜でのCl-分泌が持続する。

\section{4）腸管運動異常が関与する下痢}

甲状腺機能元進症や過敏性大腸症候群, 迷走神 経切断術, カルチノイド症候群, 回盲部切除術, 糖尿病神経症などによる下痢は喘動運動の亢進,
異常により腸管内容物の腸管内停滞時間の短縮が 関与している。この中には分泌性下痢を基本とす る下痢もあり運動異常との相乗効果による.また 腸管運動の低下によるものとして強皮症やmixed connective tissue diseaseなどの膠原病や術後の 盲係蹄症候群, 糖尿病神経症などがある。これは 腸内容物の停滞により小腸内の細菌の過㮃增殖や 脂肪の吸収障害を生ずる。この結果, 2 hydroxy胆 汁酸や10水酸化ステアリン酸による分泌性下痢を 来たすため二次性の分泌性下痢とも言える，糖尿 病の場合，腸上皮細胞の $\alpha_{2}$ アドレナージック・レ セプターの刺激が $\mathrm{Na}^{+}$の吸収促進や $\mathrm{Cl}^{-}$の分泌抑 制の作用を有していることがわかっており，この 機能障害による分泌性下痢の関与も否定できな い. アルコール常飲者の下痢は腸管の運動九進, 膵機能障害, 腸粘膜の二糖類分解䣲素活性の低下 など種々の要因により水吸収の低下が生ずる。

この他, 多くの薬物 (抗生物質, 抗不整脈薬, 降圧薬，抗癌薬，NSAID etc）で下痢を生ずるが 下剂服用を隱して下痢を主訴とする患者の存在も 忘れてはならない。

\section{おわりに}

水輸送とはあまり関係ないが多くの疾患, 病態 
と関連する $\mathrm{Ca}^{2+}, \mathrm{Mg}^{2+}, \mathrm{Fe}^{2+}$, 無機りン酸 $\left(\mathrm{HPO}_{4}{ }^{2-}, \mathrm{H}_{2} \mathrm{PO}_{4}{ }^{-}\right)$)膜輸送に関する知見も集積 している。特に $\mathrm{Ca}^{2+}$ は十二指腸, 空腸で主に吸収 され，Vit. D依存性であるが弤娠, 授乳時, 成長 の著しい時には大腸での吸収も增加する，膜透過 性は極めて低く特異的なチャネルやトランスポー ターによって細胞内に入り年側底膜からはCaポン プや $\mathrm{Na}^{+} / \mathrm{Ca}^{2+}$ アンチポーターによって能動的に 体液側に汲み出される。このCaポンプ活性が老化 や本態性高血圧》で低下していることが動物実験

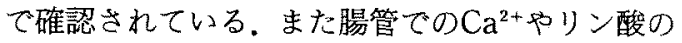
先天性の輸送障害がくる病の病因のひとつにも なっている。

体液のホメオスターシス維持のための腸管の重 要性を述べてきたが，尿生成における近位尿細管 の等張性再吸収や集合管における種々のイオン輸 送様式やその調節機構がそれぞれ近位空腸, 遠位 結腸に類似した部分も多く興味深いところであ る. しかし, 内分泌, 傍内分泌の標的㵴器として の大腸の果たしている役割はいまだ末解決の部分 が多い.

\section{文 献}

1) Ikuma $M$, Hanai $\mathrm{H}$ : Effects of aging on the microclimate $\mathrm{pH}$ of the rat jejunum. in press.

2）佐藤嘉嬖，花井洋行：モルモット大腸イオン輸送 に対するバソプレシンの作用，消化と吸収 18 : $23,1995$.

3) Morita $\mathrm{H}$, Hosomi $\mathrm{H}$ : Effects of portal infusion of hypertonic solution on jejunal electrolyte transport in anesthetized dog. Am J Physiol 259: R1289, 1990.

4) Sasaki S, Fushimi $K$ : Water channels in the kidney collecting duct. Kidney Intern $48: 1082$, 1995.

.5) 花井洋行, 金子榮藏：消化管症候群(下巻)。コレ ラ：日本臨斨，領域別淀侯群シリーズ, No 6, p206, 1994.

6) Hanai H, Kaneko E: Properties of two calcium transport systems of isolated rat ileal epithelial cells : Effects of $\mathrm{Ca}^{2+}$ channel modulators and membrane potential examined with fluorescent dye, fura-2. Eur J Physiol 419: 184, 1991.

7) Yamada $M$, Hanai $H$ : Decreased calcium pump activity in duodenal epithelial cells from spontaneously hypertensive rats. Proc Soc Exp Biol 203: 440, 1993.

\section{本項中の略語}

$\mathrm{ADH}$ : antidiuretic hormone

ADP : adenosine diphosphate

ATP : adenosine triphosphate

ATPase : adenosine triphosphatase

cAMP : cyclic adenosine $3^{\prime}, 5^{\prime}$-monophosphate

cGMP : cyclic guanosine $3^{\prime}, 5^{\prime}$-monophosphate
GDP : guanosine diphosphate

GTP : guanosine triphosphate

NAD : nicotinamide adenine dinucleotide NSAID : non-steroidal anti-inflammatory drug

WDHA症候群：WDHA (watery diarrhea, hypokalemia, achlorhydria) 症候群 